\title{
INCLUSIVE EDUCATION IN ELEMANTARY SCHOOL: AN EVALUATIVE STUDIES ON EDUCATIONAL INCLUSION IN WEST JAKARTA
}

\author{
Mohamad Syarif Sumantri ${ }^{1}$, Rosa Sagala ${ }^{2}$, Syamsul $^{3}$. \\ State University of Jakarta ${ }^{1}$, SDN Palmerah Jakarta Selatan ${ }^{2}$, SDN Mampang \\ Jakarta Selatan ${ }^{3}$. \\ mohamadsumantri@gmail.com \\ rosasagala@gmail.com \\ syamsul@gmail.com
}

\begin{abstract}
This study aimed to evaluate the implementation of the policy of inclusive education programs. Research using qualitative, evaluative and descriptive models based on Stake. The results showed that the input (antecedents) states that the implementation of inclusive education programs at both schools is not optimal in accordance with the guidelines for the implementation of inclusive education. Process (transcations) First, the lesson plan, due to the lack of identification and assessment at the time of admission of learners new learners, then it affects the planning of lessons to children with special needs. Second, the learning process, children with special needs that exist in every class together to learn with children in general. Third, assessment or evaluation of learning, not demanding graduation competency to children with special needs. The results (outcomes) First, the academic assessment for children with special needs are not prosecuted together with children in general. Second, the social skills of children with special needs children in general, peers. Based on the results of this research can be concluded that the implementation of policies on inclusive education program still needs improvement efforts both on the evaluation of the input (antecedents), process (transcations) and results (outcomes).
\end{abstract}

Keywords: policy evaluation, inclusive education, academic assessment, social skill

Inclusive education is expected to be one of the efforts to increase the participation of children in school or in an attempt equalization of educational opportunities and at the same time can improve the quality of education. Inclusive education is also expected to answer disparities in society with regard to the fulfillment of the rights of all citizens in the field of education. With the holding of inclusive education in public schools and vocational schools, this will affect the management of schools so that schools need the similarity of concepts and perspectives as well as adjustments in the implementation of inclusive education. Teachers and other education personnel and steakholder must have awareness that inclusive education is a vision. 
Rieser (2012) argues Inclusion in education is a process of enabling all children to learn and Participate Effectively within mainstream school systems, without segregation. It is about shifting the focus from altering disabled people to fit into society to transforming society, and the world, by changing attitudes, removing barriers and providing the right support.

Schools that organizes inclusive education by William Stainback (1992) is a school that can accept every child even though the child is disabled. Based on the Regulation of the Minister of national education number 70 of 2009 which states that inclusive education as a system of providing education that provides opportunities for all learners who have the disorder and has the potential intelligence or special talents to participate in education or learning in an educational setting together with the learners in general.

Mulyono A. (1999) defines inclusive education as an integrative education include: (1) children with special (special needs) with normal children, (2) Special education with education in general, (3) optimize the development of cognitive, emotional, physical, and intuition, (4) human as well as individual creatures social beings, (5) what kids learn in school with their duties in the future, and (6) Pancasila philosophy of life, religion, science, and art. By Berit H. J. (2001) in an inclusive society children a sense of ownership and partnership, and if children are given for various reasons have a need to receive more attention, then everyone will see it as a natural thing and will not interfere with other students in the group / class. Although inclusive provide added value for everyone involved, but according to Johnsen, there are several challenges that will impact on children, namely: the social emosioanal challenge, the challenge of instruction and skills development, the preparation of the professional challenge in the class inclusion. Friend and Bursuck (2006) identified types of activities schools undertook to become inclusive:

1. Developed mission statement that expressed the belief that all strive to meet the needs of all students.

2. Recognized that working towards inclusive environment continues each year without end.

3. Provided opportunities to discuss concerns about special needs students.

4. Included all classroom teachers, special education teachers, support staffs, administrators, parents, students in the planning for special needs students.

5. Clarified the expectations of special needs students who are integrated into a regular classroom.

6. Arranged for sharing planning and instructional time with all team members.

7. Provided adequate professional development for all staff members in pertinent topics.

8. Created a comfortable and collaborative work environment.

9. Planning addressed the needs of all students.

10. Included Pilot program in inclusion prior to full implementation. 
11.Allocated start up resources for supporting inclusive practices. Rewarded for experimentation and innovation;

12.Provided opportunities for all staff members to learn about all types of diversity.

13.Involved parents and families in the development, implementation, and evaluation of inclusive practices.

14.Developed a plan to carefully monitor the impacts of inclusive approaches.

15. Identified benchmarks for use after the first year of implementation

Research has been conducted in the Directorate of Special Education (2008) states that there are 925 inclusive schools in Indonesia, which consists of 790 schools to admit disabled students and 135 schools with an accelerated program for gifted from kindergarten to higher school level. In Botswana, for example, although the first educational policy enacted in 1977, it was not until 1994 that the provision of special education is specifically introduced (Chhabra, Srivastava, and Srivastava 2010). Mara Sapon-Shevin (2007) identified ten key lessons on inclusion Understanding the difference, perspective taking, real safety, Exclusion hurts everybody, Compassion, Giving and getting help graciously, Responsibility with each other, Honesty about the topic hard, Courage, Faith and hope .

The results Showed Sunardi (2011) in terms of institutional management, that the majority of inclusive schools had developed strategic plans (for inclusion), legally appointed coordinators, Involved related and relevant parties, and conducted regular coordination meetings. However, there were still many schools that had not restructured organisasi Reviews their school. In terms of student admission/ identification / assessment, 54\% of schools set a quota for SEN students. Only $19 \%$ applied a selection process in student admission, half of the which used different procedures for SEN candidates. Approximately $50 \%$ of inclusive schools had modified Reviews their curriculum, Including a variety of standards. In terms of instruction, $68 \%$ of inclusive schools that they modified Reported Reviews their instructional process. Only a few schools, however, Provided special equipment for students with visual impairment, physical impairment, speech and hearing problems, and autism and gifted and talented students. In a student evaluation, more than 50 percent of test items Reported that, administration, time allocations, and students' reports were modified.

Research on implementation is also have done by Latiff (2015) relating to the implementation of the Inclusive Education Program conducted in the Special Education Program Integration at an elementary school in Malacca.

The study aims to explore the basis of the comprehensive, through evaluative approach, on the implementation of inclusive education at the primary level and the results of this study are expected to be the basis for policy makers related to inclusive education in primary schools either by the local government of DKI, as well as enthusiasts of inclusive education. 


\section{METHOD}

This study uses a qualitative, evaluative and descriptive models based on Stake. The data used are primary and secondary data. The primary data obtained through interviews with informants, teachers, and students, as the executor (motorcycle taxi) on policy, while secondary data collected through the study of the documentation related to education policy inklsusif. The main data collection techniques are searches document (document tracking) and in-depth interviews (indepth interview). indicators in this study are antecedents, transcations and outcome.

This research was conducted in Pela Mampang In the state elementary school and the state elementary school 01 Pagi Tanjung Duren, West Jakarta. The object of research is inclusive education schools and their related parties teachers, assistant teachers, principals, staffs, parents, and community. The research subject is determined by purposive 5 classroom teachers, four teachers in the study, second counselor, 1 head of school, 5 parents of students with special needs, 10 students with special needs, five parents of students in general, 5 students in general, one member of the committee schools and 2 administrative staff.

Program evaluation criteria in this study was developed by the researchers based on the implementation guidelines for inclusive education in primary schools in 2010 issued by the government.

Analysis of the data by examining the gap between the facts of observation with the criteria established researchers. both qualitative and quantitative description.

\section{RESULT AND DISCUSSION}

Based on observations, interviews and document analysis according with the evaluation of the model programs stake, the the third components, namely: 1) description, 2) criteria, 3) judgment. And observed in three phases which: Antecedent, Transaction-processes Outcomes, outputs

\section{Antecedents \\ Students}

Learners enter the school through two channels, namely regular lines and special lines. Government defined processes for recruitment of learners passing admission Students New guidelines (PPDB) Online. Based on the data received by researchers from both schools, the number and types of children with special needs (Table 1). 


\section{Table 1.Data Children With Special Needs}

\begin{tabular}{|l|l|l|l|l|l|l|l|l|}
\hline Schools & $\begin{array}{l}\text { Impair } \\
\text { ed } \\
\text { Vision }\end{array}$ & $\begin{array}{l}\text { Spee } \\
\text { ch } \\
\text { disor } \\
\text { ders }\end{array}$ & $\begin{array}{l}\text { Mental } \\
\text { ly } \\
\text { disable } \\
\text { d }\end{array}$ & $\begin{array}{l}\text { Learni } \\
\text { ng } \\
\text { Disord } \\
\text { ers }\end{array}$ & $\begin{array}{l}\text { Autis } \\
\text { m }\end{array}$ & $\begin{array}{l}\text { AD } \\
\text { HD }\end{array}$ & $\begin{array}{l}\text { Emotion } \\
\text { al and } \\
\text { social }\end{array}$ & total \\
\hline $\begin{array}{l}\text { SDN 01 } \\
\text { Pela } \\
\text { Mpang }\end{array}$ & 1 & 1 & 16 & 31 & 2 & 2 & 4 & 57 \\
\hline $\begin{array}{l}\text { SDN 01 } \\
\text { Tanj. } \\
\text { Duren }\end{array}$ & 2 & 1 & 3 & 35 & 1 & 3 & 2 & 48 \\
\hline
\end{tabular}

\section{Curriculum}

Implementation of inclusive education should be adjusted and should accommodate the needs and abilities of learners in accordance with intelligence, talents, interests and potential. Here is the curriculum used in SDN 01 and SDN 01 Pela Mampang Tanjung Duren (Table 2).

Table 2. The Curriculum Used In Research

\begin{tabular}{|l|l|l|}
\hline Schools & Curriculum 2013 & KTSP \\
\hline SDN 01 Pela Mampang & Class I dan IV & Class II, III, IV, dan VI \\
\hline SDN 01 Tanjung Duren & Class III, V, dan VI & Class I, II, dan IV \\
\hline
\end{tabular}

For children with special needs, the curriculum used modified in accordance with the conditions and the ability of each child, so was born the Individual Education Program for each Special needs children. However, curriculum modification is still not running in accordance with the guidelines. This is supported by observations and interviews with teachers, they reveal that the guidelines only give general directives that the curriculum for the inclusive school is a curriculum modifications without given sample (picture) curriculum. The situation of children are diverse and specific needs that kind of assortment as add new tasks in the manufacture of Individual Education Program (PPI).

\section{Teacher}

Teachers who are in the country Elementary school 01 Pela Mampang berjmulah 15 people with backgrounds different from the education. Data educators who teach in public elementary schools 01 Pela Mampang (Table 3). 
Table 3. Data of Teachers in Public Elementary School Pela Mampang 01

\begin{tabular}{|l|l|c|}
\hline No & Educational Background & Total \\
\hline 1 & Elementary School Teacher & 3 \\
\hline 2 & Religious Education & 1 \\
\hline 3 & English Education & 2 \\
\hline 4 & Language and Literature & 1 \\
\hline 5 & Law & 1 \\
\hline 6 & Special Education & 1 \\
\hline 7 & Counseling & 1 \\
\hline 8 & Civics & 1 \\
\hline 9 & Office administration & 1 \\
\hline 10 & Education Indonesian & 15 \\
\hline 11 & Administration & \\
\hline & Total & 1 \\
\hline
\end{tabular}

Based on the table above the State Elementary School 01 Pela Mampang teachers have exceptional educational background to handle children with special needs. While at the State Elementary School 01 Tanjung Duren there are 16 classroom teachers and one headmaster. His educational background do not derive from Special Education. There is no also of psychology. Responsible for children with special needs is the classroom teacher. The following table 3 on the data presented teacher at the State Elementary School 01 Tanjung Duren (Table 4).

\section{Table 4. Data Of Teachers In Public Elementary School Tanjung Duren 01}

\begin{tabular}{|l|l|c|}
\hline No & Educational Background & Total \\
\hline 1 & Elementary School Teacher & 5 \\
\hline 3 & English Education & 2 \\
\hline 4 & Language and Literature & 2 \\
\hline 5 & Law & 2 \\
\hline 8 & Civics & 2 \\
\hline 9 & Office administration & 1 \\
\hline 10 & Education Indonesian & 1 \\
\hline 11 & Administration & 1 \\
\hline & Total & 16 \\
\hline
\end{tabular}

With all the limitations provision of their knowledge, the teachers teach classes and devote his life to the students, armed with genuine love and perseverance to educate every child, especially those children with special needs. Children with special needs that exist in every class together to learn with children in general. With the condition there is only one class teacher, without any special teacher assistant. Even if there is a special assistant in the number of teachers is 
only one teacher for one school. This situation does not correspond to the number of children with disabilities at each school. Therefore, the learning process in the classroom to maximize the role of teacher and classroom management, if children with special needs require additional mentoring and teaching, the classroom teachers willingly gave his time after school.

\section{Facilities and Infrastructure}

In principle, inclusive school facilities and infrastructure are not much different from regular schools, but to make schools welcoming for all needs to include accessibility that can help ease the mobility and not endanger all learners with special needs.

\section{Funding}

Funding for schools designated to conduct an inclusive education program in accordance with the regulations, given the financial support to meet the special services provided to each child with special needs. But the researchers from both schools, both elementary school and the city, 01 Pela Mampang Elementary School 01 country Tanjung Duren, no funding is given by the local education departmentFinancing / funding for schools designated by the local education department if it complies with the regulations, the school that organizes inclusive education programs are given special funds to perform services to children with special needs in the school. So that all the limitations and obstacles children with special needs accommodated properly through funding. But in both these schools, do not get the financial support they should.

The results of the research findings on aspects Input, indicates that the completeness and the readiness of the organization of the inclusive education program by $78 \%$, completeness and readiness is in the category, good / high. Organizing inclusive education program was conducted in South Jakarta Mampang Elementary School, this activity is considered important by the teachers and the school community, therefore readiness and completeness of implementation of inclusive education have demonstrated good condition. This needs to be maintained in order to improve children's services learning disabilities at the elementary level.

Facilities and infrastructure are adequate, the facilities and infrastructure that support is sufficient but needs maintenance and care of the board and all members, so that the infrastructure continues to be used. Implementation and assessment of learning outcomes in the classroom inclusion in progress $69.87 \%$ were thus need to be improved so that better in the future, so that this implementation could make students uncomfortable and sincerely, in accepting the material for the implementation of learning in the classroom.

Preparation and completeness of learning in inclusive education to be very important in achieving the best quality, it is in accordance with the opinion of 
Mittler, P. (2012) the quality of inclusive education must be supported learning system components.

\section{Transcations:}

\section{Classroom management}

The system used in Pela Mampang inclusive school SDN 01 and SDN 01 Pagi Tanjung Duren is a regular class that is in the classroom full of students with special needs learn together with regular participants.

\section{Planning Learning}

Master class inclusive schools have not been able to develop learning tools (syllabus / curriculum development) based on individual differences in the classroom so as to form individual learning program (PPI) specifically implemented for children with special needs. Most people still equate diversity so that children with special needs only to get the material that the difficulty level is lower than the general participants. Preparation of learning tools that teachers (syllabus, lesson plans, worksheets, LP and Materials) has not adjusted to the results of the assessment of children with special needs. Factors not held identification and assessment of ongoing activities in the classroom.

\section{Learning implementation}

Setting the classroom that teachers are merandom seat student / student each week. Reference teacher in the learning process refers to the standard process (elaboration, exploration, confirmation) not implementing the strategies and grip varied according to the characteristics and needs of diverse learners.

Limitations of instructional media used are also not able to accommodate student/ student with special needs. Teachers simply use the media within the reach of regular learners. Several media for children with special needs were obtained from the government are not used because the learning time and energy is inadequate.

As for the implementation of service learning in school children learning disabilities Inclusion or the findings of the aspects of the activities of teachers in the classroom by using the observation sheet. The overall results of the assessment can be seen in the following(Table 5): 
Tabel 5. Learning process

\begin{tabular}{|l|l|c|c|}
\hline No & Teacher name & Scores Average & \% Of max score \\
\hline 1 & Bp IK & 3,82 & 68,58 \\
\hline 2 & Ibu WS & 3,23 & 67,96 \\
\hline 3 & Ibu BB & 3,44 & 68,90 \\
\hline 4 & Ibu ST & 3,475 & 69,50 \\
\hline 5 & Bp AS & 3,56 & 74,44 \\
\hline Scores Average & 3,50 & 69,87 \\
\hline
\end{tabular}

Based on the findings of the study was the process of serving children learning disabilities, it becomes very important in implementing inclusive education fairly. Learning process that shows the activities of teachers and students who are active, meaningful, fun, conducive and oriented to the professional teachers. As Mastropieri, M. A., \& Scruggs, T. E. (2012) statement that the learning process is fair and active is the best feature of the learning process of inclusion.

\section{Outcomes :}

The results of the research findings on the competence of teachers in inclusive schools, there are aspects of the output of the evaluation issues related to program objectives that have been set by the education department, which is in the competence of teachers in the understanding of inclusive education, State Primary School Mampang, South Jakarta. As for some of the discussion can be described as the description below:

Table 6. Competency Test Results

\begin{tabular}{|c|l|c|}
\hline No & Competency & $\begin{array}{c}\% \text { Of the value of } \\
\text { the Maximum }\end{array}$ \\
\hline 1 & Pedagogic competence & 62,74 \\
\hline 2 & Professional competence & 63,14 \\
\hline 3 & Personal competence & 73,6 \\
\hline 4 & Social competence & 71,33 \\
\hline
\end{tabular}

Based on these data, researchers can conclude there are two score pedagogic and professional competence in the general knowledge education of children learning disabilities, is still not satisfactory that is $62.74 \%$ and $63.14 \%$ after a general knowledge test special education services so as more is necessary training programs to prepare children learning disabilities in inclusive education in primary schools. 


\section{Assessment or evaluation of learning}

Of the two schools that became the object of research, the assessment made for children with special needs in given specificity. Taking into account the condition of the child or natural barriers. Thus, in the academic assessment is not the same with children in general. Tailored to the child's academic assessment disturbances they have. While evaluating the social skills of teachers view of the development of each child with special needs good observation each time the teacher do the teaching in the classroom and on the assessment of their peers.

Evaluation of student learning in the service learning disabilities into the main requirement in inclusive education, because every child can not be equated abilities in one class, the teacher eventually need a fair assessment system and remain oriented cognitive, affective and skill Ainscow, M. (2005) stated that comprehensive and objective evaluation should performed on each student.

\section{CONCLUSION}

The following conclusions are drawn from this research. The first antecedents, implementing inclusive education programs at both schools is not optimal in accordance with the guidelines for the implementation of inclusive education. Second transcations, three things are evaluated, namely lesson planning, instructional implementation, and evaluation or assessment of learning. the learning process in the classroom teachers have not been up for children with special needs require additional mentoring and teaching AGR get special services according to the needs. Outcome Third, the focus of outcomes is academic success skills and social skills of children with special needs. Objective evaluation of the results obtained by the teachers do a good cooperation with parents of children with special needs. Both in academic results and life skills of children with special need to be improved.

\section{REFERENCE}

Ainscow, M. (2005). Developing inclusive education systems: what are the levers for change? Journal of educational change, 6(2), 109-124.

Ab.Latiff, Maizatul Azmah. (2015). Implementation of Inclusive Education For Special Needs Learners with Learning Disabilities, Journal Elsevier, 204 ( 2015 ) $81-87$.

Anonim. (2014).Pedoman Penyelenggaran pendidikan Inklusi di Sekolah Dasar. Jakarta: Direktorat Pendidikan Luar Biasa. Indonesia.

Berit H. Johnsen. (2001). Special Needs Education-An Introduction (translation). (Bandung: Graduate School of Education University of Indonesia

Chhabra, Simmi, Rama Srivastava, and Ishaan Srivastava. (2010). "Inclusive Education in Botswana: The Perception of School Teachers." Journal of Disability Studies 20 (4): 219-228. 
Directorate of Special Education. 2008. Special Education in Figures. Jakarta: Ministry of National Education. National Education Minister Regulation Number 70 of 2009.

Joko Widodo, (2007). Public Policy Analysis Concepts and Applications Analysis of Public Policy Process, Malang: Bayumedia Publishing.

Mulyono Abdurrahman, (1999). Pendidikan Anak berkesulitan Belajar. Education For Children learning disabilities. Jakarta: Rineka Copyright.

Mastropieri, M. A., \& Scruggs, T. E. (2012). The inclusive classroom: Strategies for effective differentiated instruction. Pearson Higher Ed.

Mittler, P. (2012). Working towards inclusive education: Social contexts. Routledge.

Richard Rieser. (2012). Implementing Inclusive Education, United Kingdom:Charlesworth Press,

Sapon-Shevin, Mara. (2007). Widening the Circle: The Power of Inclusive Classrooms. Boston: Beacon Press,.

William Stainback, (1992). Controversial Issues Confronting Special Educational. India: Allyn and Bacon 